\title{
Thanatophoric dysplasia: a rare entity
}

\section{Sangeeta Arya*, Kiran Pandey, Disha Gupta, Shefali Pande}

Department of Obstetrics \& Gynecology, G.S.V.M. Medical College, Kanpur, UP, India

Received: 11 December 2013

Accepted: 15 December 2013

\author{
*Correspondence: \\ Dr. Sangeeta Arya, \\ E-mail: sangeetaanilverma@gmail.com
}

(C) 2014 Arya S et al. This is an open-access article distributed under the terms of the Creative Commons Attribution Non-Commercial License, which permits unrestricted non-commercial use, distribution, and reproduction in any medium, provided the original work is properly cited.

\begin{abstract}
Thanatophoric dysplasia (TD), a rare and lethal skeletal dysplasia of neonatal period. Two clinical forms of Thanatophoric dysplasia have been described. TD is caused by specific autosomal dominant mutations in the gene that codifies for the Fibroblast Growth Factor Receptor 3 (FGFR3). The mutations constitutively activate the tyrosine kinase activity of the receptor. The estimated birth incidence is approximately $1 / 20,000$ to $1 / 50,000$. TD I being more frequent than TD II. Most individuals with TD die within the first few hours or days of life. Currently, specific therapeutic regiments do not exist. Prenatal diagnosis is available, both by ultrasonography and by molecular studies. This case report describes fetus with one of this rare disorder.
\end{abstract}

Keywords: Thanatophoric dysplasia, Skeletal dysplasia, Pregnancy

\section{INTRODUCTION}

Thanatophoric dysplasia (TD) is the most common form of skeletal dysplasia that is lethal in the neonatal period. The term, thanatophoric, derives from the Greek word thanatophorus, which means "death bringing" or "death bearing." Thanatophoric dysplasia has an incidence of 1 per 20,000-50,000 births. ${ }^{1}$ In Indian literature, a few isolated cases are described. ${ }^{2}$ However, several indications of under-registration suggest that the real value is about twice that observed. Males and females are equally affected. TD is caused due to mutation of the fibroblast growth factor receptor 3 gene (FGFR3), which is located on the short arm of chromosome 4. The mutation results in the activation of FGFR3 tyrosine kinase independently of ligands such as fibroblast growth factor 8. It was reported that hypochondroplasia, achondroplasia and thanatophoric dysplasia are the different types of mutation in FGFR3 with hypochondroplasia being the mildest and TD, the most severe form. ${ }^{3}$ Since the clinical profile of this anomaly was rarely reported, we discuss the anatomical features, abnormalities and clinical profile of TD in the present report.

\section{CASE REPORT}

A 32 year old G4P2L2A1, healthy, nonconsanguineously married woman with no significant medical or obstetric history at 24 weeks of gestation was brought to hospital for routine antenatal check-up and was advised USG for fetal well-being. The pregnancy was uneventful. Ultrasound examination revealed a single live fetus. Amniotic fluid index was normal. Femur, humerus and other long bones were very short with femoral length equivalent to 12-14 weeks. Bi-parietal diameter of fetus was corresponding to 23 weeks of gestation. Thoracic cavity was too small and irregular. At this stage Thanatophoric dwarfism was considered. A second USG repeated after one week confirmed the previous findings and hence diagnosis was confirmed. After consulting the family members and mother decision for medical termination of pregnancy was considered for which consent in proper format was taken. Misoprost (PGE1) was used for induction of labor. A 24 week fetus was delivered. APGAR were 4, 5 and 5 at $1 \mathrm{~min}, 5 \mathrm{~min} \&$ $10 \mathrm{~min}$. Baby survived for one hour and died due to respiratory distress and cardiorespiratory arrest probably due to pulmonary hypoplasia. On examination newborn weighed 850 grams and was small in length. There was 
macrocephaly, depressed nasal bridge, and small face. Both the upper and lower limbs were extremely short along with brachydactyly. Lower limbs were curved. Chest was small and thoracic cage appeared funnel shaped. Radiological examination revealed all long bones to be curved, short long bones with reduced density of bones.

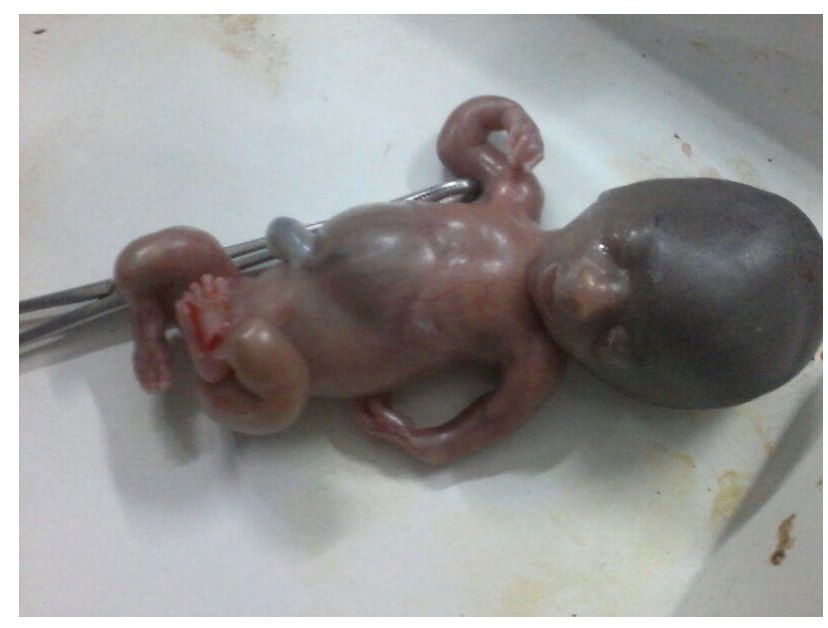

Figure 1: Actual photograph.

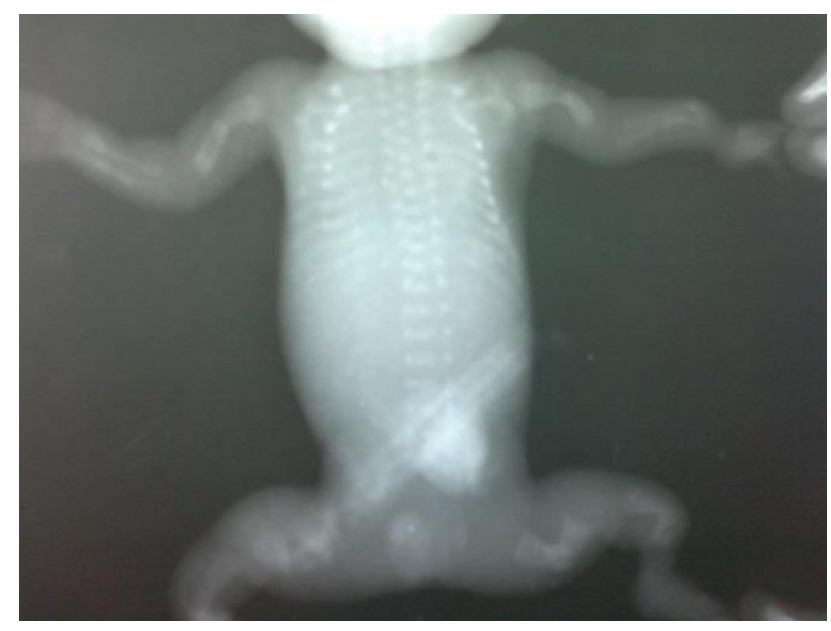

Figure 2: Infantogram.

\section{DISCUSSION}

Thanatophoric dysplasia or dwarfism (TD) is characterized by severe limb shortening (micromelia), bowing of limbs, narrow thorax and protuberant abdomen. Other features include polyhydramnios, macrocephaly, large anterior fontanel, frontal bossing, cloverleaf skull, prominent eyes, hypertelorism, flat facies with low nasal bridge, marked shortening of the limbs (micromelia), trident hand with brachydactyly, redundant skin folds, narrow, bell-shaped thorax with short ribs and protuberant abdomen, relatively normal trunk length, generalized hypotonia, small pelvis. It was observed that the abnormal temporal lobe development is a common associated feature and can be visualized as early as the second trimester on ultrasound.

TD is an autosomal dominant condition. There have been two types of TD observed. Type I TD is characterized by marked underdeveloped skeleton and short-curved long bones. The pelvic bones and vertebral columns are underdeveloped, cloverleaf skull may or may not be present. ${ }^{4}$ Whereas in type II TD, the long bones are not as short as in type I and are not bent. The fetuses with type II TD are reported to have cloverleaf skull which means a tri-lobed skull. The premature closures of coronal and lambdoid sutures are commonly seen with the cloverleaf skull.FGFR3 mutants are the cause of both TDI and TDII. For TDI a series of missense mutations have been identified: R248C*, Y373C*, S249C, G370C, S371C. The most common mutants (*) account for $60-80 \%$ of TDI. Furthermore, stop codon mutations (X807L, X807G, X807R, X807C, X807W) have been identified. ${ }^{5}$ For TDII a single point mutation in the FGFR3 gene (K650E) has been identified. ${ }^{6}$

\section{Diagnosis criteria}

The identification of a severe skeletal dysplasia in the second trimester is usually straight forward, but establishing a specific diagnosis like TD can be rather difficult. $^{7}$

\section{Table 1: Diagnosis criteria.}

\begin{tabular}{|c|c|}
\hline $\begin{array}{l}\text { Prenatal ultrasonographic } \\
\text { features }\end{array}$ & Radiographic features \\
\hline $\begin{array}{ll}\text { - } & \text { Growth deficiency } \\
\text { recognizable by } 20 \\
\text { weeks gestation } \\
\text { - Well-ossified spine and } \\
\text { skull; cloverleaf skull for } \\
\text { TD II; sometime in TD I } \\
\text { - } & \text { Platyspondyly, bowed } \\
& \text { femurs (for TD I) } \\
\text { - } & \text { Ventriculomegaly } \\
\text { - Narrow chest cavity with } \\
\text { short ribs } \\
\text { - } & \text { Polyhydramnios }\end{array}$ & $\begin{array}{ll}\text { - } & \text { Rhizomelic } \\
\text { shortening and } \\
\text { irregular } \\
\text { metaphyses of the } \\
\text { long bones } \\
-\quad \text { Platyspondyly } \\
-\quad \text { Small formen } \\
\text { magnum } \\
\text { - } \\
\text { Bowed femurs (for } \\
\text { TD I) }\end{array}$ \\
\hline
\end{tabular}

Differential diagnosis ${ }^{8,9}$ includes achondrogenesis, achondroplasia, asphyxiating thoracic dystrophy (Jeune syndrome), hypophosphatasia, osteogenesis imperfecta.

The counseling part of management is very important in this disease, especially to the parents of the affected children. Without proper genetic counseling, most families having had a fetus with TD would be too worried to have further pregnancy. ${ }^{2}$ Since the majority of cases of TD occur sporadically, it is important to counsel that the recurrence risk is low for only one previously affected fetus and that the extended family members of the proband are not at increased risk. A general empiric recurrence risk for this entity was estimated to be only 
$2 \%$. To relieve the parental anxiety in such low risk couple, prenatal ultrasound examination may be offered in subsequent pregnancies to identify features suggestive of TD. If indicated, amniocentesis may be offered and the diagnosis may be done by molecular analysis. It was reported that the prenatal diagnosis of TD has been well established with ultrasound examination usually in the second trimester. The 3D anatomy scan and molecular confirmation may be helpful in early diagnosis and genetic counseling of TD. Prenatal diagnosis is performed by analysis of DNA (FGFR3 sequences) extracted from fetal cells obtained by amniocentesis usually performed at 15-18 weeks gestation or chorionic villus sampling at about 10-12 weeks gestation. Routine prenatal ultrasound examination may identify skeletal alterations associated to TD such as cloverleaf skull, very short extremities, and a small thorax.

Early neonatal death in TD may be due to reduced thoracic dimensions causing pulmonary hypoplasia. Malformations, deformations and potentially significant neuro-axial injury, principally at the level of the atlas vertebrae may also contribute to the death. Recently, many reports of patients with TD surviving the neonatal period have been documented in literature and one patient had survived 5.2 years. ${ }^{10}$ Most individuals with TD die within the first few hours or days of life by respiratory insufficiency secondary to reduced thoracic capacity or compression of the brainstem. Management concerns are limited to extreme life support measures for the newborn. Brain stem compression resulting from hydrocephalus which may develop beyond the neonatal period also contributes to ventilator insufficiency. Surgical interventions by decompressions of brain stem in small foramen magnum have allowed prolonged survival in some of these cases.

\section{Funding: No funding sources}

Conflict of interest: None declared

Ethical approval: Not required

\section{REFERENCES}

1. Lam AC, Lam YY, Tong TM et al. Thanatophoric dysplasia type 1 (TD 1) without "telephone receivers”. HK J Paediatr. 2006;11:320-3.
2. Bajaj P, Mangwana S, Logani KB, Kumari S, Gupta AK. Thanatophoric dwarfism. Indian Pediatr. 1993;30:802-5.

3. Cohen MM Jr. Achondroplasia, hypochondroplasia and thanatophoric dysplasia: clinically related skeletal dysplasias that are also related at the molecular level. Int $\mathrm{J}$ Oral Maxillofac Surg. 1998;27(6):451-5.

4. Langer LO Jr, Yang SS, Hall JG, Sommer A, Kottamasu SR, Golabi $M$ et al. Thanatophoric dysplasia and cloverleaf skull. Am J Med Genet Suppl. 1987;3:167-79.

5. Rousseau A., Saugier P., Le Merrer M., Munnich A., Delezoide A. L., Maroteaux P., Bonaventure J., Narcy F., Sanak M. Stop codon FGFR3 mutations in thanatophoryc dwarfism type 1 . Nat Genet. 1995;10:11-2.

6. Gorlin R. J. Fibroblast growth factors, their receptors and receptor disorders. J Craniomaxillofac Surg. 1997;25:69-79.

7. Sawai H., Komori S., Ida A., Henmi T., Bessho T., Koyama K. Prenatal diagnosis of thanatophoric dysplasia by mutational analysis of the fibroblast growth factor receptor 3 gene and a proposed correction of previously published PCR results. Prenat Diagn. 1999;19:21-4.

8. Gorlin R. J., Cohen M. M., Hennekam R. C. M. Syndromes of the Head and Neck. In: Gorlin R. J., Cohen M. M., Hennekam R. C. M., eds. The Chondrodysplasias. 4th ed. New York: Oxford University Press; 2001: 481.

9. Lee S. H., Cho J. Y., Song M. J., Min Y. J., Ban B. H., Lee Y. H., Cho B. J., Kim S. H. Fetal musculoskeletal malformations with a poor outcome: ultrasonographic, pathologic and radiographic findings. Korean J Radiol. 2002; 3:113-24.

10. MacDonald IM, Hunger AGW, MacLeod PM, MacMurray SB. Growth and development in thanatophoric dysplasia. Am J Med Genet. 1989;33:508-12.

DOI: $10.5455 / 2320-1770$. ijrcog20140353

Cite this article as: Arya S, Pandey K, Gupta D,

Pande S. Thanatophoric dysplasia: a rare entity. Int J Reprod Contracept Obstet Gynecol 2014;3:251-3. 